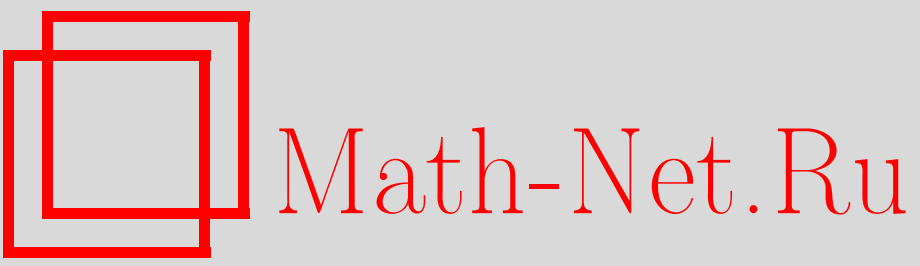

Ф. А. Богомолов, Н. И. Дубровин, В. А. Исковских, В. С. Куликов, А. Н. Паршин, И. Р. Шафаревич, Геннадий Владимирович Белый (некролог), УМН, 2002, том 57, выпуск 5, 139-140

DOI: https://doi.org/10.4213/rm554

Использование Общероссийского математического портала Math-Net.Ru подразумевает, что вы прочитали и согласны с пользовательским соглашением

http: //www. mathnet.ru/rus/agreement

Параметры загрузки:

IP : 18.234 .156 .22

26 апреля 2023 г., 17:48:11 


\section{ГЕННАДИЙ ВЛАДИМИРОВИЧ БЕЛЫЙ}

29 января 2001 г. во Владимире внезапно скончался Геннадий Владимирович Белшй.

Г. В. Белшй родился 2 февраля 1951 г. в городе Магнитогорске. Затем родители переехали на Украину, в Днепропетровскую область. В 1968 г. Г.В.Белшй окончил киевскую физико-математическую школу-интернат и поступил на механико-математический факульет Московского государственного университета им. М.В. Ломоносова. После окончания мех-мата МГУ с 1973 г. по 1975 г. работал в Киеве и Львове. В 1975-78 гг. был аспирантом Математического института им. В.А. Стеклова АН СССР, где его научным руководителем был И.Р. Шафаревич. В 1979 г. защитил кандидатскую диссертацию, а годом раньше стал преподавать на кафедре высшей математики Владимирского государственного университета сначала в должности ассистента, затем старшего преподавателя, а с 1982 г. - доцента.

Основные работы Г. В. Белого посвящены алгебре и теории чисел, прежде всего теории Галуа полей алгебраических чисел.

Несколько лет после окончания университета он напряженно думал над тем, как можно построить расширения с простыми группами Галуа над полем рациональных чисел или круговыми полями, исходя из известной конструкции таких расширений над полями $\mathbb{C}(T)$ и $\overline{\mathbb{Q}}(T)(\mathbb{C}$ - поле комплексных чисел, $\overline{\mathbb{Q}}$ - поле всех алгебраических чисел).

В результате многолетних усилий он нашел очень простое условие на конечную группу $G$, когда ее можно реализовать как группу Галуа какого-то кругового расширения поля $\mathbb{Q}$. Это условие состоит в существовании в группе $G$ такой системы образующих $g_{1}, \ldots, g_{k}$ с соотношением $g_{1} \cdots g_{k}=1$, что любые элементы $g_{1}^{\prime}, \ldots, g_{k}^{\prime}$, по отдельности сопряженные $g_{1}, \ldots, g_{k}$ и связанные тем же соотношением, получаются из $g_{1}, \ldots, g_{k}$ сопряжением одним и тем же элементом группы $G$. Это условие эффективно проверяемо и с его помощью было показано, что целый ряд конечных простых групп реализуется как группы Галуа расширений круговых полей. В некоторых случаях удавалось эти группы реализовать и как группы расширений поля рациональных чисел. Это был совершенно неожиданный прорыв в обратной задаче теории Галуа. В последующие несколько лет Г.В. Бельй показал, что его условие выполняется для большинства простых групп "лиевского типа" над конечными полями, так что и они реализуются как группы Галуа расширений круговых полей. Тема была подхвачена другими авторами, значительно расширившими область применения этих идей. Сейчас обратная задача теории Галуа решена этим методом над круговьги полями почти для всех простых групп. Для ряда простых групп она решена и над полем рациональных чисел (например, для знаменитого "Монстра") $)^{1}$.

Эта работа Г. В. Белого была его кандидатской диссертацией. Во время защиты диссертации оценка ее была столь высокой, что было сделано и обсуждалось предложение присудить за нее докторскую степень. К сожалению, какие-то формальности помешали это сделать.

\footnotetext{
${ }^{1}$ См. обзор в кн. Д. Гильберт, Избранные труды, т. I, М.: Факториал, 1998, с. 522-523.
} 
В этой же работе Г.В. Белый при помощи очень простых соображений (на одной странице текста) вывел неожиданньй критерий того, когда алгебраическая кривая может быть определена над некоторым полем алгебраических чисел (т.е. над $\overline{\mathbb{Q}})$. Условие заключается в том, что кривая является накрытием проективной прямой с тремя точками ветвления.

Интересно, что в это же время этот критерий был сформулирован в качестве гипотезы А. Гротендиком, у которого она играла существенную роль в комбинаторном подходе к теории многообразия модулей алгебраических кривых, предложенным им и известном как теория "детских рисунков". В своих воспоминаниях Гротендик пишет, что рассказал об этой гипотезе П. Делиню и тот сообщил ему, что она толюко что доказана Белым (ничего не знавшим о предположении Гротендика). Гротендик пишет, что "никогда столько мыслей не было изложено в столь малом числе строк", как в этом доказательстве Белого.

Этот резултат Г.В. Белого, ставший известным как теорема о трех точках, за последние годы получил многочисленные применения в самых разных областях алгебраической геометрии. Упомянем лишь часть этих применений. Развивая метод его доказательства,. . А. Богомолов и Т. Пантев нашли очень простое доказательство существования гладкой проективной модели для любого алгебраического многообразия над полем нулевой характеристики ${ }^{2}$. Метод Белого позволил ему вложить группу Галуа поля $\overline{\mathbb{Q}}$ над $\mathbb{Q}$ в группу автоморфизмов свободной группы от двух образующих. В дальнейшем это вложение привело к нахождению весьма нетривиальных связей с группой автоморфизмов группы кос (В. Г. Дринфелшд, Я. Ихара).

Одной их характерных черт Г.В. Белого было его необычайное упорство. Он годами думал над задачами, хотя всем уже казалось, что имевшиеся у него соображения недостаточны для их решения. И в результате у него появлялись новые соображения, которые и давали решение.

Последние годы Г. В. Бельй занимался так назьваемым "спектром Маркова" или "числами Маркова". Здесь положение выглядело похоже на его занятия теорией Галуа. Казалось, что его громадные математические возможности не адекватны тем задачам, которые имеются в этой области. Но он упорно продолжал ею заниматься. И можно думать, что если бы ему было дано еще несколько лет жизни, то оказалось бы, что он прав.

Выдающийся вклад Г. В. Белого в алгебру и теорию чисел высоко оценен математиками всего мира. Ему была присуждена премия Московского математического общества (1981). Бельй был приглашенньм докладчиком на Международном математическом конгрессе в Беркли (США) в августе 1986 года. В 90-е годы он участвовал во многих конференциях и работал в целом ряде математических институтов (Чикаго, Гейдельберг, Гёттинген, Берлин, Бонн).

Друзья и коллеги Геннадия Владимировича Белого потрясены известием о его неожиданной кончине. Его безвременный уход из жизни - огромная потеря для всех знавших его.

Ф. А. Богомолов, Н. И. Дубровин, В. А. Исковских, В. С. Куликов, А.Н. Паршин, И. Р. Шафаревич

\section{СПИСОК НАУЧНЫХ ТРУДОВ Г. В. БЕЛОГО}

[1] О серровских алгебрах Ли обобщенных якобианов // Матем. заметки. 1976. Т. 19. № 4. С. 571-576 (совм. с В.А. Королевичем)

[2] О расширениях Галуа максималшного кругового поля // Изв. РАН. Сер. матем. 1979. Т. 43. № 2. C. $267-276$

[3] On extensions of the maximal cyclotomic field having a given classical Galois group // J. Reine Angew. Math. 1983. V. 341. P. 147-156

[4] Коммутант абсолютной группы Галуа // Proc. Internat. Congress Math., (Berkeley, 1986). T. 1. Providence, RI: Amer. Math. Soc., 1987. C. 346-349

[5] Another proof of three points theorem // Preprint MPI-1997-46

[6] Markoff's Numbers and Quadratic Forms // Preprint MPI-1997-47

[7] Перевод работы Д. Гильберта "О неприводимости многочленов с целочисленными коэффиициентами" // Д. Гильберт. Избранные труды. Т. І. М.: Факториал, 1998. С. 128-147

[8] Числа Маркова и квадратичные формы // Труды международной конференции, посвященной 90-летию со дня рождения Л.С. Понтрягина. Т. 8 (Алгебра). Итоги науки и техники. Совр. матем. и ее прил. (Темат. обзоры). Т. 69. М.: ВИНИТИ, 1999. С. 5-23

[9] Другое доказательство теоремы о трех точках // Матем. сб. 2002. Т. 193. № 3. С. 21-24

\footnotetext{
${ }^{2}$ F. A. Bogomolov, T. Pantev, Weak Hironaka theorem, Math. Res. Lett. 1996. V. 3. P. 299-308.
} 